\title{
Past atmospheric trace metal deposition in a remote lake (Lake Ngoring) at the headwater areas of Yellow River, Tibetan Plateau
}

\author{
Hong Zhang • Baoqing Shan • Liang Ao • \\ Wenzhong Tang $\cdot$ Shengfang Wen
}

Received: 18 August 2013/Accepted: 13 November 2013/Published online: 29 November 2013

(C) Springer-Verlag Berlin Heidelberg 2013

\begin{abstract}
A complete record derived from a core dated both by ${ }^{210} \mathrm{~Pb}$ and ${ }^{137} \mathrm{Cs}$ chronologies from Lake Ngoring at the headwater areas of the Yellow River provides new insight into the changing atmospheric deposition of trace metals including $\mathrm{Cd}, \mathrm{Cr}, \mathrm{Cu}, \mathrm{Ni}, \mathrm{Pb}$, and $\mathrm{Zn}$. This study showed that there was an inflection in the early 1960s, before which both fluxes and contents of $\mathrm{Cd}, \mathrm{Ni}, \mathrm{Pb}$, and $\mathrm{Zn}$ remained relatively steady or slowly increased, and thereafter continued increases both in fluxes and contents were found. Taking $\mathrm{Pb}$ as an example, the flux increased from 0.13 (before 1960) to $0.25 \mathrm{mg} \mathrm{m}^{-2} \mathrm{a}^{-1}$ (averaged 1963-2006). According to atmospheric flux calculations using $\mathrm{Al}$ as a reference element, atmospheric fluxes of trace metals generally showed a rapid increase and peaked in recent years, closely following the historical economic development of the neighboring region, mainly for Qinghai and Gansu provinces. The atmospheric inventory for $\mathrm{Zn}$ was the highest, reaching $1.068 \mathrm{~g} \mathrm{~m}^{-2}$, while the lowest was for $\mathrm{Cd}$, at only $0.079 \mathrm{gm}^{-2}$. The percentage proportions of atmospheric deposition for $\mathrm{Cd}, \mathrm{Ni}$, and $\mathrm{Zn}$ were 37 , 12 , and $8.7 \%$, respectively. Hence, the atmospheric contribution to the trace metal content via long range transport
\end{abstract}

H. Zhang · B. Shan $(\bowtie) \cdot$ W. Tang $\cdot$ S. Wen

State Key Laboratory of Environmental Aquatic Chemistry, Research Center for Eco-Environmental Sciences, Chinese Academy of Sciences, 18 Shuangqing Rd, Haidian District, Beijing 100085, China

e-mail: bqshan@rcees.ac.cn

H. Zhang

e-mail: hongzhang@rcees.ac.cn

L. Ao

Chongqing Academy of Environmental Sciences,

Chongqing, China is not negligible when considering input of materials to lake ecosystems.

Keywords Tibetan plateau - Yellow river - Trace metals - Atmospheric deposition - Remote lake

\section{Introduction}

The atmosphere is a significant pathway for the movement and redistribution of some trace metals within the ecosystem (Lantzy and Mackenzie 1979). Some anthropogenic trace metals are capable of undergoing long range transport (LRT) in the atmosphere and undergo dry and/or wet deposition (Jeffries and Snyder 1981) upon encountering relatively cold environments such as those at high latitude or elevation, including the Tibetan Plateau (Yang et al. 2007). A precipitate, often in the form of snow, is believed to be an efficient scavenger of atmospheric contaminants (Franz and Eisenreich 1998; Carrera et al. 2001). When considering input of materials to aquatic and terrestrial ecosystems, these findings clearly indicate the potential for significant atmospheric input of trace metals, particularly for the enriched elements via LRT from a source area. Atmospheric inputs of $\mathrm{Hg}$ and $\mathrm{Pb}$, as well as subsequent depositions have been intensively studied, especially in Europe and North America (Yang et al. 2010; Madsen 1981; Shotyk et al. 1998; Pacyna and Pacyna 2001), but equivalent data for other trace metals such as $\mathrm{Cu}, \mathrm{Cd}$, and $\mathrm{Zn}$ are more scarce and there is now concern with respect to the increase in atmospheric inputs from this region to global cycles (Nriagu 1996), which is exacerbated by highly populated and rapidly industrializing countries in the surrounding regions.

The Tibetan Plateau is one of the most remote and isolated regions in the world. It is a unique landscape and 
the source of many major rivers such as the Yellow River, Yangtze River, and Langcang River in Asia. Hence, it is a source of water for half the world's population. As much of the Tibetan Plateau lies above the atmospheric boundary layer, East Asian summer and winter monsoons, the Indian summer monsoon and the Westerly jet prevail in this area. Lakes in this region offer 'natural experiments' on exposure to atmospheric LRT contaminants. Lake sediments are thought to be natural archives that provide a historical record of environmental change within a lake and its catchment, as well as trends in atmospheric deposition; thus, trace-metal-containing lacustrine sediment can be uniquely related to atmospheric deposition in the area. Due to the difficulty of sampling, studies of atmospheric deposition of trace metals in this monsoon-affected area, especially long-time change based on dated sediments, have been relatively scarce. Wang et al. (2010) and Jin et al. (2013) investigated sedimentary trace metals and estimated the atmospheric $\mathrm{Pb}$ deposition rate in Lake Qinghai since the 1960s. However, Lake Qinghai had been subjected to trace metal pollution of some metallurgic plants (Wang et al. 2010), and this lake had been developed for leisure activities and fishing, thus such human activities were deemed to increase the anthropogenic trace metal inputs via wastewater discharge; if those input loads could not be excluded, the atmospheric metal deposition rate in this region would be overestimated.

Lake Ngoring, located in the source area of the Yellow River, which was thought to receive pollutants solely from atmospheric deposition, was selected to gain a better understanding of both the regional and global cycle of trace metals. It is in a scarcely populated zone $(<4$ people per $\mathrm{km}^{2}$ ) with absolutely no industry within the watershed, thus atmospheric deposition is the only anthropogenic source of trace metal accumulation in the lake. In this study, a sediment core was collected from Lake Ngoring to reconstruct the trace metal input history using both ${ }^{210} \mathrm{~Pb}$ and ${ }^{137} \mathrm{Cs}$ chronologies, to examine the distribution and fractionations of sedimentary trace metals in the lake, and further to estimate atmospheric deposition rates of the studied metals. This is the first report about Lake Ngoring from a limnological perspective, and historical pollution data would be very useful to understanding the impact of regional economic development in the remote environment of this lake.

\section{Materials and methods}

Study area and background

Lake Ngoring and Lake Gyaring are sister lakes (Fig. 1), comprising the largest bodies of fresh water in the Yellow River basin. The water from the Yellow River converging from the Kar Stream and Yoigilangleb Stream (the source of the Yellow River) flows into Lake Gyaring from the southwestern corner and out from the southwestern corner, with a great deal of sand, so the surface is gray when the wind stirs. Ngoring Lake $\left(34^{\circ} 46^{\prime}-35^{\circ} 05^{\prime} \mathrm{N}\right.$, 97 $32^{\prime}-$ $97^{\circ} 54^{\prime} \mathrm{E}$ ), also called "E'ling Sea", is situated in the hollow land of western Maduo county at the north margin of the Qinghai-Tibetan Plateau, $15 \mathrm{~km}$ off Gyaring Lake to the west. The water surface altitude is $4,272 \mathrm{~m}$ above present sea level, more than 1,000 m higher than Lake Qinghai. Snowmelt and rainfall comprise the major inputs, the water flows into the lake from the southwestern corner and out from the northeastern corner, draining a catchment area of $18,188 \mathrm{~km}^{2}$, and there is no evidence of any land-use change or active land management within the catchment. A cold and semi-arid continental climate, sensitive to the Asia monsoons, Indian monsoon and the Westerly jet, prevails in the entire Lake Ngoring basin, and the air temperature varies from $7.6^{\circ}$ in July to $-16.5^{\circ}$ in January, averaging $-3.8^{\circ}$ (1953-2005). The mean annual precipitation (1953-2005) is $314 \mathrm{~mm}$, but evapotranspiration is three times higher.

The average water depth of Lake Ngoring is about $17.6 \mathrm{~m}$ (maximum $30.7 \mathrm{~m}$ ), with a surface area of $610 \mathrm{~km}^{2}$, and a capacity of 10.7 billion $\mathrm{m}^{3}$. The lake is thought to become thermally stratified in summer and is covered by ice from late October to early April. However, as it is located in a remote scarcely populated zone, no limnological studies have been conducted so far on this plateau freshwater lake. Based on our field investigation, aquatic plants only grow in the riparian areas, fish in the lake are rare, and bioturbation in the lake sediments is considered to be negligible. Thus sediment in this lake provides ideal conditions for historical reconstruction of heavy metal contamination and further estimation of the atmospheric inputs of trace metals on the regional scale.

Sample collection and analysis

A sediment core (NG06-07) was sampled from the southeast part of Lake Ngoring in July 2007 (Fig. 1) using a selfmade core sampling device, with an inner diameter of $70 \mathrm{~mm}$ and a length of $1,000 \mathrm{~mm}$. The sediment core was extruded and sectioned in $1 \mathrm{~cm}$ slices sequentially. Water content was determined from a subsample of each slice, and the remaining material was freeze-dried for further analysis. Dried sediments were ground in an agate mortar and sieved $(100 \mu \mathrm{m})$ prior to analysis.

The specific activities of both ${ }^{210} \mathrm{~Pb}$ and ${ }^{137} \mathrm{Cs}$ were detected using gamma ray spectrometry (ORTEC, USA) on a DSPEC jr 2.0 multi-channel spectrometer coupled with GWL-120-15 well detector. Peaks of ${ }^{210} \mathrm{~Pb},{ }^{214} \mathrm{~Pb}$ (daughter of ${ }^{226} \mathrm{Ra}$ ), and ${ }^{137} \mathrm{Cs}$ used to determine activity were at $46.52,352$, and $661.6 \mathrm{keV}$, respectively. Standard samples 


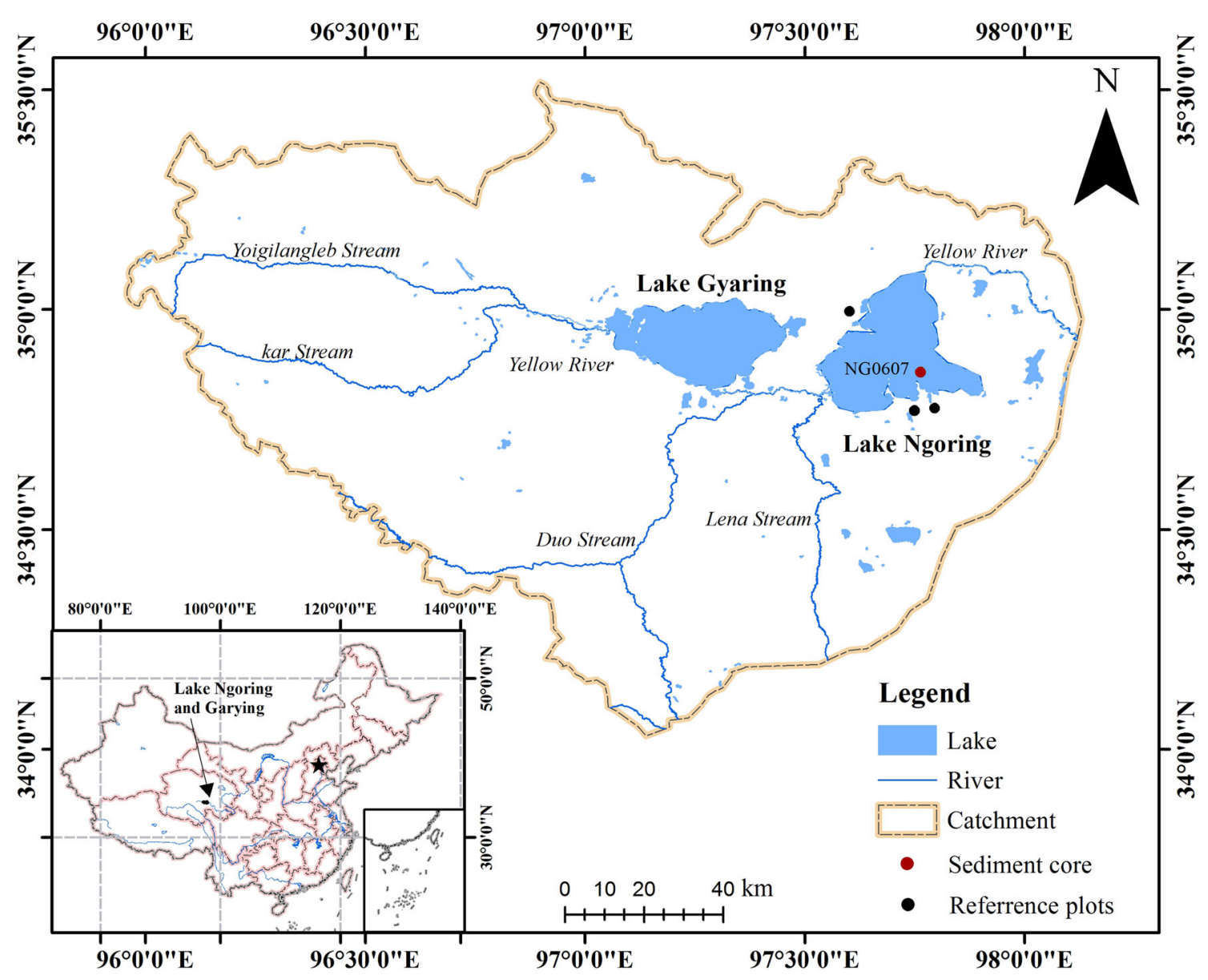

Fig. 1 Map of the Lake Ngoring with sampling sites and location

for both ${ }^{210} \mathrm{~Pb}$ and ${ }^{137} \mathrm{Cs}$ were supplied by the Institute of Atomic Energy, Chinese Academy of Sciences. Excess ${ }^{210} \mathrm{~Pb}$ activity was obtained by subtracting ${ }^{226} \mathrm{Ra}$ activity from total ${ }^{210} \mathrm{~Pb}$ activity and application of the constant rate of supply (CRS) dating model (Appleby 2002).

For trace metal analysis, $0.1 \mathrm{~g}$ sediment sample was digested with $6 \mathrm{ml}$ aqua regia and $2 \mathrm{ml}$ hydrofluoric acid at $180^{\circ}$ for $20 \mathrm{~min}$ in a microwave digestion apparatus (CEM MARS 5, USA) following the procedure recommended by the United States Environmental Protection Agency (USEPA, no. 3051a). All of the above solutions were stored at $4{ }^{\circ} \mathrm{C}$ prior to analysis. Inductively Coupled Plasma-Mass Spectrometry (ICP-MS) was used to determine the $\mathrm{Cd}, \mathrm{Cr}, \mathrm{Cu}, \mathrm{Ni}, \mathrm{Pb}$, and $\mathrm{Zn}$ concentrations.

Quality assurance and quality control of results

Quality assurance and quality control of the analytical procedure for sedimentary trace metals $(\mathrm{Cd}, \mathrm{Cr}, \mathrm{Cu}, \mathrm{Ni}, \mathrm{Pb}$, and $\mathrm{Zn}$ ) determinations were carried out using method blanks and certified reference material (GBW 07305) purchased from the National Research Center for Certified
Reference Materials of China. Five blanks were treated identically to the samples in each batch, and the mean concentrations over all batches were $0.017 \pm 0.002$ (Mean $\pm \mathrm{SD}$ ) $\mathrm{mg} \mathrm{Cd} \mathrm{kg} \mathrm{g}^{-1}, 1.8 \pm 0.26 \mathrm{mg} \mathrm{Cr} \mathrm{kg} \mathrm{g}^{-1}$, $1.5 \pm 0.9 \mathrm{mg} \quad \mathrm{Cu} \quad \mathrm{kg}^{-1}, \quad 0.57 \pm 0.19 \mathrm{mg} \quad \mathrm{Ni} \quad \mathrm{kg}^{-1}$, $1.7 \pm 0.6 \mathrm{mg} \mathrm{Pb} \mathrm{kg}^{-1}$, and $2.5 \pm 0.8 \mathrm{mg} \mathrm{Zn} \mathrm{kg}^{-1}$ assuming $0.1 \mathrm{~g}$ weight, respectively, which had been subtracted correspondingly from sediment samples. Recoveries for $\mathrm{Cd}, \mathrm{Cr}, \mathrm{Cu}, \mathrm{Ni}, \mathrm{Pb}$, and $\mathrm{Zn}$ were 96.0, 94.1, 92.7, 95.0, 94.8 and $93.8 \%$ averaged over all batches, respectively. Five replicates of the certified reference standards showed relative standard deviations for $\mathrm{Cd}, \mathrm{Cr}, \mathrm{Cu}, \mathrm{Ni}, \mathrm{Pb}$, and $\mathrm{Zn}$ of 4.6, 4.2, 4.4, 3.9, 4.0 and $4.4 \%$, respectively.

\section{Results and discussion}

Core chronology

Excess ${ }^{210} \mathrm{~Pb}\left({ }^{210} \mathrm{~Pb}_{\mathrm{ex}}\right)$ activity showed an exponential decrease with depth in the sediment core profile (Fig. 2), further confirming the absence of bioturbation in these 

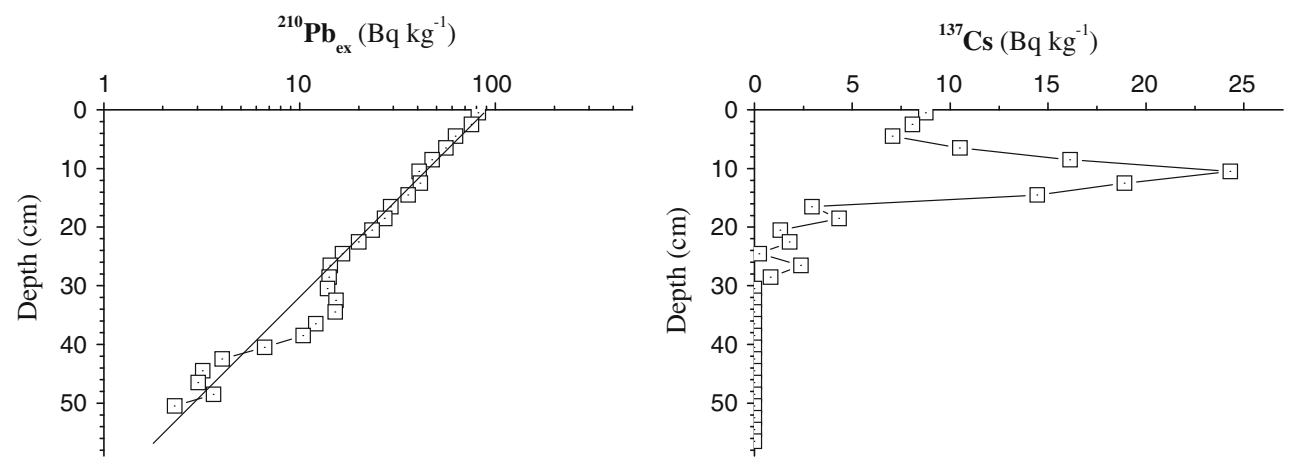

Fig. 2 Fallout radionuclide concentrations in sediment core (NR06-01) from Lake Ngoring, showing ${ }^{210} \mathrm{~Pb}$ ex , and ${ }^{137} \mathrm{Cs}$ profiles
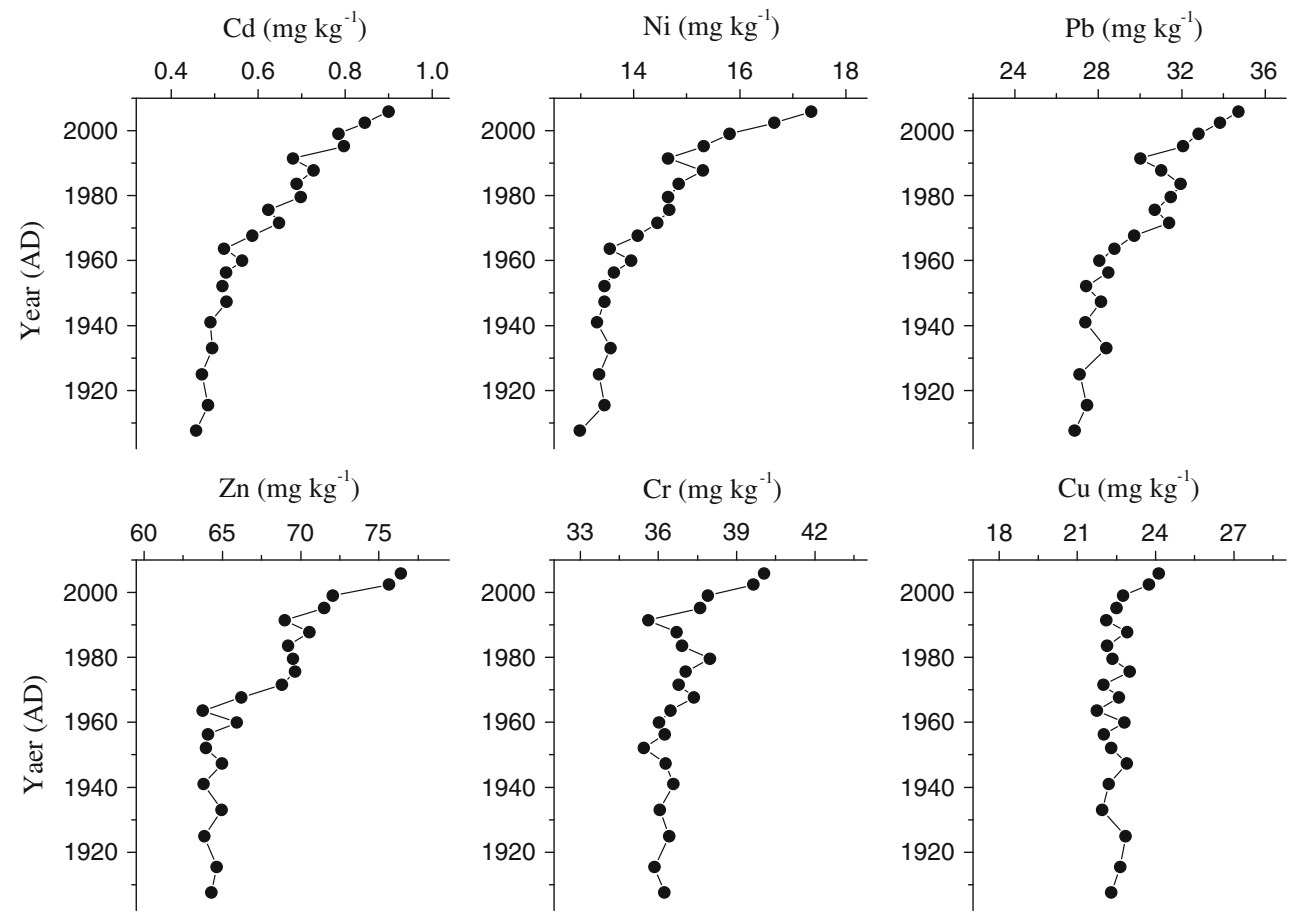

Fig. 3 Content profiles of $\mathrm{Ni}, \mathrm{Cu}, \mathrm{Zn}, \mathrm{Cd}, \mathrm{Pb}$, and $\mathrm{Cr}$ in the sediment core from Lake Ngoring at the headwater areas of the Yellow River, Tibetan Plateau

sediments. The $1986{ }^{137} \mathrm{Cs}$ peak was clearly visible at core depths of 10-11 cm, but the 1963 peak was indistinct, which was similar to the study by (Jin et al. 2010) at Lake Qinghai. The exponential decrease of ${ }^{210} \mathrm{~Pb}_{\mathrm{ex}}$ in the sediment core suggested that bulk sediment accumulated at a relatively constant rate in the basins. Core chronologies are shown on the sediment profiles in Figs. 3, 4, 5. The ${ }^{210} \mathrm{~Pb}$ dates were in good agreement with the ${ }^{137} \mathrm{Cs}$ dates of the sediment core in Lake Ngoring. For example, at 10-11 cm depth, where the peak of ${ }^{137} \mathrm{Cs}$ activity was assumed to be due to the Chernobyl event in 1986, the CRS model yielded a date of AD 1987, and at 29-30 cm depth, where the first detection of ${ }^{137} \mathrm{Cs}$ activity was assumed to correspond to AD 1952 (Benoit and Rozan 2001), the CRS model yielded dates of AD 1952. The mean linear sedimentation rate was
$0.41 \mathrm{~cm} \mathrm{a}^{-1}$, which was sufficient to provide good temporal resolution for studying modern pollution trends.

Average mass accumulation rates (MAR) inferred from the ${ }^{210} \mathrm{~Pb}$ and ${ }^{137} \mathrm{Cs}$ dates were 356 and $379 \mathrm{mg} \mathrm{cm}^{-2}$ year $^{-1}$, respectively, which were relatively higher than that in Lake Qinghai by a factor of 5 (Han et al. 2007), although both of them were remote lakes in Tibetan Plateau. MAR in Lake Ngoring was also higher as compared with shallow lakes in southeast of China, such as Lake Chaohu (Zan et al. 2012) and Lake Taihu (Bing et al. 2011). This might be attributed to the high suspended solids' concentration of the inflowing river from the upper lake (Lake Gyaring). Yellow River is known as a silt-carrying river in the world, especially in headwater areas, and Gyaring means the white long lake in Tibetan language because of high load of silt 

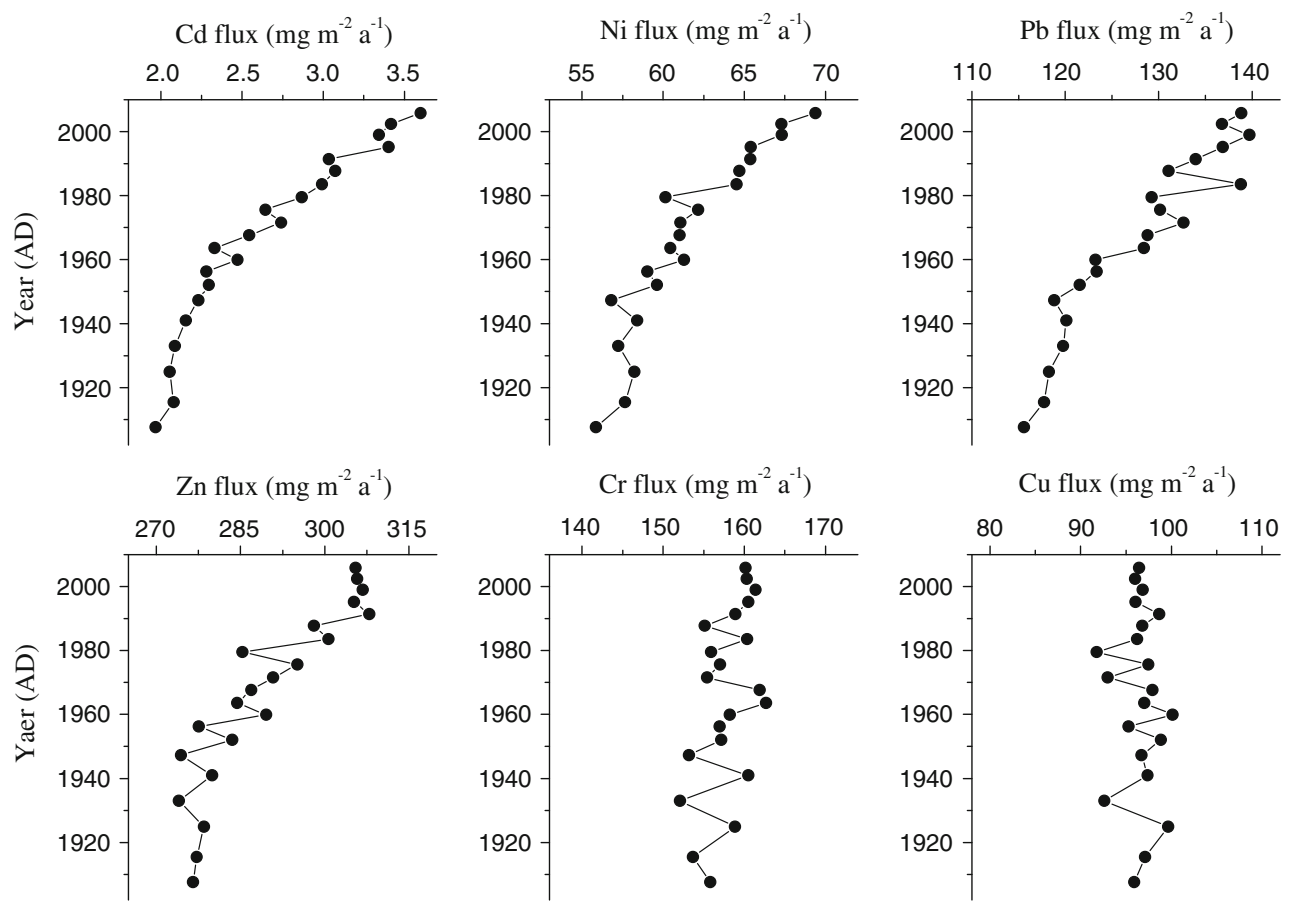

Fig. 4 Depositional flux profiles of $\mathrm{Ni}, \mathrm{Cu}, \mathrm{Zn}, \mathrm{Cd}, \mathrm{Pb}$, and $\mathrm{Cr}$ in the sediment core from Lake Ngoring at the headwater areas of the Yellow River, Tibetan Plateau

and sand inputs of the Yellow River. Although a majority of silt and sand has been deposited in the Lake Gyaring, particle content in the inflowing water to Lake Ngoring is still relatively high, resulting in a higher MAR in Lake Ngoring.

Abundance and flux of trace metal in sediments

For the affinity adsorption to sediment particles, trace metal contents in sediment were thought to stand for the level of trace metals during transportation and deposition to some extent. Contents of trace metal profiles in sediment core are presented in Fig. 3, ranging in the intervals 13.0-17.4, 21.8-24.1, 63.8-76.4, 0.46-0.92, 26.9-34.7, and $35.5-40.1 \mathrm{mg} \mathrm{kg}^{-1}$ for $\mathrm{Ni}, \mathrm{Cu}, \mathrm{Zn}, \mathrm{Cd}, \mathrm{Pb}$, and $\mathrm{Cr}$, respectively. Although trace metal contents varied in an element-dependent fashion, surface samples showed the highest concentration values for all the six elements. The content profiles of $\mathrm{Cd}, \mathrm{Ni}, \mathrm{Pb}$, and $\mathrm{Zn}$ show a general increasing trend from deeper parts of the core towards to the surface; whereas a similar trend was only displayed in the surface layers for profiles of both $\mathrm{Cr}$ and $\mathrm{Cu}$, and in deeper parts they remained relatively constant. For other elements, $\mathrm{Cd}$ and $\mathrm{Ni}$ were increasing slightly before the $1960 \mathrm{~s}$, averaging 0.50 and $13.5 \mathrm{mg} \mathrm{kg}^{-1}$, respectively, but thereafter, they increased steeply, reaching 0.92 and $17.4 \mathrm{mg} \mathrm{kg}^{-1}$, respectively. As for $\mathrm{Pb}$ and $\mathrm{Zn}$, similar trends could also be observed, while a relatively steady period was displayed during the 1970s to 1980s, while the contents kept increasing sharply thereafter for both of them. Although they fluctuated, the contents of $\mathrm{Cu}$ and $\mathrm{Cr}$ before the 1990s were relatively stable and averaged 22.4 and $36.5 \mathrm{mg} \mathrm{kg}^{-1}$, respectively.

Generally, contents of trace metals in sediments in Lake Ngoring were lower than those in sediments reported from other areas (Table 1). Among the Chinese lacustrine sediments, trace metal contents in this study were almost the lowest, with only those from Lake Qinghai being comparable. Trace metal contents in the sediment of Lake Ngoring were much lower than that of both Lake Chaohu and Lake Taihu in the lower reaches of Yangtze River, an industrial region in southeastern China, and this was the same when compared with lakes in both Switzerland and UK. This indicated limited local trace metal contribution to the remote Lake Ngoring.

The fluctuation of mass accumulation rates may cause dilution or accumulation of trace metals in sediments, thus fluxes were calculated by multiplying the content by the corresponding sedimentation rate for a certain year (layer), and the depositional flux profiles of $\mathrm{Ni}, \mathrm{Cu}, \mathrm{Zn}, \mathrm{Cd}, \mathrm{Pb}$, and $\mathrm{Cr}$ are depicted in Fig. 4, which gives more accurate pictures of trace metal contamination trends than the trace metal content profiles. The total $\mathrm{Zn}$ flux was the highest, reaching approximately $306 \mathrm{mg} \mathrm{m}^{-2} \mathrm{a}^{-1}$ in recent years, whereas the $\mathrm{Cd}$ flux was the lowest, no more than $4 \mathrm{mg} \mathrm{m}^{-2} \mathrm{a}^{-1}$ within in all the dated years, and the fluxes 
Table 1 Comparison of trace metal contents in lake sediments from other lakes $\left(\mathrm{mg} \mathrm{kg}^{-1}\right)$

\begin{tabular}{llllllll}
\hline Location & $\mathrm{Cd}$ & $\mathrm{Cr}$ & $\mathrm{Cu}$ & $\mathrm{Ni}$ & $\mathrm{Pb}$ & $\mathrm{Zn}$ & $\mathrm{References}$ \\
\hline Lake Ngoring, China & $0.46-0.92$ & $35.5-40.1$ & $21.8-24.1$ & $13.0-17.4$ & $26.9-34.7$ & $63.8-76.4$ & This study \\
Lake Qinghai, China & $0.14-0.28$ & $53.8-63.5$ & $23.5-33.8$ & $27.8-31.9$ & $18.0-24.0$ & $68.0-75.0$ & Wang et al. 2010 \\
Lake Daihai, China & - & - & $33.6-41.7$ & - & $21.5-36.0$ & - & Han et al. 2007 \\
Lake Chaohu, China & - & $46.9-130$ & $12.6-52.3$ & $1.8-74.1$ & $22.7-83.1$ & $48.4-355$ & Han et al. 2011 \\
Lake Taihu, China & - & - & $16.4-38.9$ & $24.7-51.2$ & $29.6-56.1$ & $48.2-113$ & Xue et al. 2010 \\
Lochnagar, Scotland & $0.3-1.9$ & - & $8.0-25.0$ & - & $100-360$ & $39.0-180$ & Yang et al. 2002 \\
Lake Zurich, Switzerland & $0.2-19.0$ & - & $20.0-78.0$ & - & $10.0-150$ & $50.0-675$ & VonGunten et al. 1997 \\
\hline
\end{tabular}

for $\mathrm{Ni}, \mathrm{Cr}, \mathrm{Cu}$, and $\mathrm{Pb}$ averaged from all involved years were $61.6,158,96.6$ and $128 \mathrm{mg} \mathrm{m}^{-2} \mathrm{a}^{-1}$, respectively. Similar trends could also be observed between content and flux profiles and there is an inflection around 1960. Before 1960s, all fluxes remained relatively steady or slowly increased; taking $\mathrm{Pb}$ for example, the average increase rate of flux before 1960 was $0.13 \mathrm{mg} \mathrm{m}^{-2} \mathrm{a}^{-1}$. However, continued increases of $\mathrm{Cd}, \mathrm{Ni}, \mathrm{Pb}$, and $\mathrm{Zn}$ fluxes were found during 1963-2006, also taking $\mathrm{Pb}$ as an example, the average increasing rate in this period was $0.25 \mathrm{mg} \mathrm{m}^{-2}$ $\mathrm{a}^{-1}$, larger by a factor of two compared that before 1960 , and $\mathrm{Pb}$ flux increased from $128 \mathrm{mg} \mathrm{m}^{-2} \mathrm{a}^{-1}$ in 1963-139 $\mathrm{mg} \mathrm{m}^{-2} \mathrm{a}^{-1}$ in 2006. Similarities could also be observed in flux profiles of $\mathrm{Cd}, \mathrm{Ni}$, and $\mathrm{Zn}$. However, there were different patterns for $\mathrm{Cr}$ and $\mathrm{Cu}$; although their concentrations displayed an increasing trend after 1990 (Fig. 3), relatively stable fluxes of both metals were observed (Fig. 4). At over 4,200 m, the watershed lies in a scarcely populated zone $\left(<4\right.$ people per $\mathrm{km}^{2}$ ) with absolutely no industry, and it is above the limit of sheep and cow grazing in the region, moreover, there is no evidence of any land-use change or active land management within the watershed. Thus similarities between variations in $\mathrm{Ni}$, $\mathrm{Zn}, \mathrm{Cd}$, and $\mathrm{Pb}$ after 1960s, both in total contents and total fluxes, suggest enhanced inputs of atmospheric deposition.

\section{Calculation of fluxes of atmospheric trace metals}

To reduce the trace metal variability caused by grain size and mineralogy of the sediments, and to identify atmospheric metal contributions and fluxes, geochemical normalization has been used with various degrees of success by employing conservative elements, and among these $\mathrm{Al}$ and $\mathrm{Li}$ are the most widely used elements. In addition, a reference element must be strongly correlated to the fine fraction and not dependent on anthropogenic inputs. $\mathrm{Al}$ is often used as a conservative element because of the relative stability in sedimentation, which meets this requirement (Summers et al. 1996; Covelli and Fontolan 1997; Dai et al. 2007). Trace metal contents were normalized to Al to account for variations in the contribution of lithogenic origin or background to total concentrations in the sediment core, providing an estimate of the natural inputs of trace metals, mainly from in-washed eroded soil. The atmospheric flux of a certain trace metal $\left(\mathrm{F}_{\text {atmospheric }}\right)$ was the difference between total and the lithogenic flux, which was calculated using the method promoted by Jin et al. (2010):

$\begin{aligned} \mathrm{F}_{\text {atmospheric }}= & {\left[\mathrm{Me}_{\text {sample }}-\mathrm{Al}_{\text {sample }} \times(\mathrm{Me} / \mathrm{Al})_{\text {baseline }}\right] } \\ & \times \text { MAR }\end{aligned}$

where $\mathrm{Me}_{\text {sample }}, \mathrm{Al}_{\text {sample }}$ are contents of the trace metal, and $\mathrm{Al}$ in the sediments, respectively; $(\mathrm{Me} / \mathrm{Al})_{\text {baseline }}$ are contents of the trace metal and Al of soil samples taken from the average composition of 3 reference plots in the Ngoring Watershed (Fig. 1); MAR are mass accumulation rates.

Atmospheric fluxes of trace metals closely followed the historical economic development of neighboring region mainly for Qinghai and Gansu provinces. The Chinese government launched the 'Reform and Open' Policy in 1978 and 'Western Development' Policy in 2000, so the recent three decades, especially since the year 2000, is the fastest urbanization period that West China has ever experienced. During this fast economic increase period, atmospheric fluxes of trace metals generally show a rapid increase and peaked in recent years, except for $\mathrm{Cr}$ and $\mathrm{Cu}$. Take $\mathrm{Pb}$ for instance, the anthropogenic flux increased $41 \%$, from 15.6 to $22.0 \mathrm{mg} \mathrm{m}^{-2} \mathrm{a}^{-1}$, and 54, 104, and $83 \%$ for $\mathrm{Cd}, \mathrm{Ni}$, and $\mathrm{Zn}$, respectively (Fig. 5). Global anthropogenic $\mathrm{Pb}$ emissions have been greatly reduced since the 1970s (Nriagu 1996), and this reduction of $\mathrm{Pb}$ in deposition has been recorded in ice cores (Boutron et al. 1991), ombrotrophic bog peat cores (Vile et al. 2000), and lake sediments (VonGunten et al. 1997). However, lake sediments in the Tibetan Plateau do not record this reduction in $\mathrm{Pb}$, nor for the other five metals. The increased atmospheric fluxes of trace metals reflect the growing trace metal load during the last decades in parallel to the rapid urbanization and economic development in of neighbor region, mainly for Qinghai and Gansu province. 
Fig. 5 Atmospheric flux profiles of $\mathrm{Ni}, \mathrm{Cu}, \mathrm{Zn}, \mathrm{Cd}, \mathrm{Pb}$, and $\mathrm{Cr}$ in the sediment core from Lake Ngoring at the headwater areas of Yellow River, Tibetan Plateau
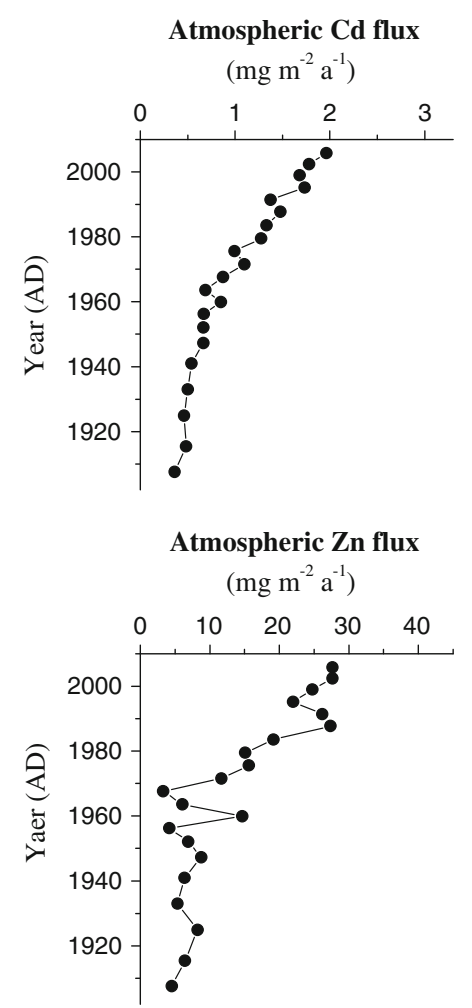
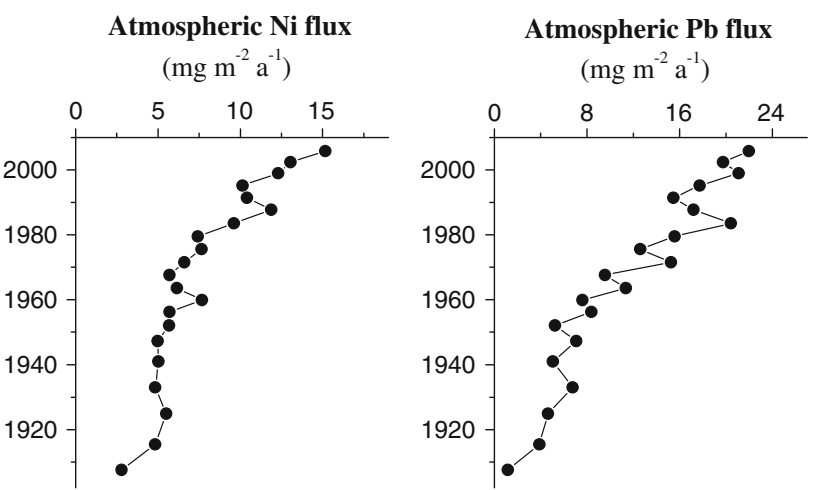

Atmospheric Cr flux $\left(\mathrm{mg} \mathrm{m}^{-2} \mathrm{a}^{-1}\right)$

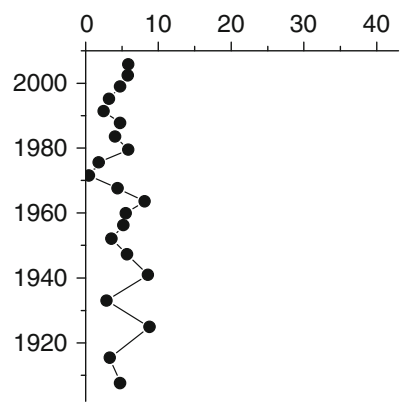

Atmospheric Cu flux $\left(\mathrm{mg} \mathrm{m}^{-2} \mathrm{a}^{-1}\right)$

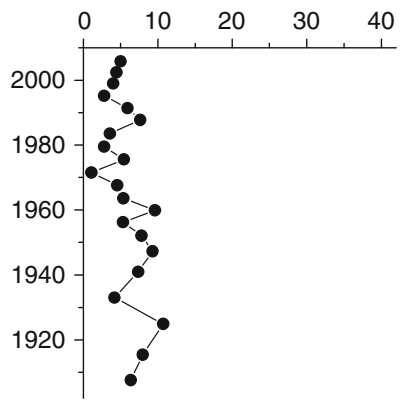

From the 1960s to the 1970s was the period of the 'Three Years of Natural Disasters' followed by the 'Cultural Revolution' in China. Although economic development was disrupted, an increase in atmospheric fluxes for $\mathrm{Cd}, \mathrm{Ni}, \mathrm{Pb}$, and $\mathrm{Zn}$ was observed. Similar trends were also found in Lake Qinghai and some other remote lakes in the Tibetan Plateau (Jin et al. 2010). A dramatic increase in anthropogenic $\mathrm{Pb}$ deposition since the 1960s is consistent with the regional/global trend in $\mathrm{Pb}$ emissions to the atmosphere (Nriagu 1989). In Lake Ngoring, increased anthropogenic fluxes of trace metals since the 1960s could be attributed to regional industrial sources and fuel combustion, especially in south Asia, as well as local construction activities for roads, highways, and railways around 1960 (Jin et al. 2010; Wang et al. 2010), which increased trace metal emission via combustion of leaded gasoline used by trucks and other construction machinery.

Before 1960s, about $0.57 \mathrm{mg} \mathrm{Cd} \mathrm{m}^{-2}, 5.2 \mathrm{mg} \mathrm{Ni} \mathrm{m}^{-2}$, $5.5 \mathrm{mg} \mathrm{Pb} \mathrm{m}^{-2}, 7.3 \mathrm{mg} \mathrm{Zn} \mathrm{m}^{-2}, 5.3 \mathrm{mg} \mathrm{Cr} \mathrm{m}^{-2}$, and $7.6 \mathrm{mg} \mathrm{Cu} \mathrm{m}^{-2}$ of atmospheric metals had been deposited annually in Lake Ngoring on average (Fig. 5), and all of the atmospheric fluxes were relatively stable although they fluctuated. There was evidence of widespread atmospheric trace metal pollution during the late 19th and early 20th centuries, likely from coal burning, from lake sediment and peat core archives (Nriagu 1989, 1996; Shotyk et al. 1998). It is possible therefore that LRT metal might be partly responsible for the observed pre-1960s atmospheric fluxes
Table 2 Estimation of total (T) and atmospheric (A) inventories of trace metals in the sediment of the Lake Ngoring $\left(\mathrm{g} \mathrm{m}^{-2}\right)$ and percentage proportion of $\mathrm{A} / \mathrm{T}(\%)$

\begin{tabular}{lccllll}
\hline & $\mathrm{Cd}$ & $\mathrm{Cr}$ & $\mathrm{Cu}$ & $\mathrm{Ni}$ & $\mathrm{Pb}$ & $\mathrm{Zn}$ \\
\hline Total & 0.214 & 13.06 & 8.00 & 5.05 & 10.51 & 23.88 \\
Atmospheric & 0.079 & 0.392 & 0.489 & 0.604 & 0.912 & 1.068 \\
$\begin{array}{c}\text { Proportion } \\
(\mathrm{A} / \mathrm{T} \%)\end{array}$ & 37.1 & 3.00 & 6.10 & 11.96 & 8.68 & 4.42 \\
\hline
\end{tabular}

to the lake sediments, together with some degree of mixing of the regional input at the historical sediment-water interface.

Inventories of trace metals in the sediment core, estimated as the product of content times dry weight of each slices of the sediment core and then summed together, yielded $0.209 \mathrm{~g} \mathrm{Cd} \mathrm{m}^{-2}, 13.06 \mathrm{~g} \mathrm{Cr} \mathrm{m}^{-2}, 8.00 \mathrm{~g} \mathrm{Cu} \mathrm{m}^{-2}$, $5.05 \mathrm{~g} \mathrm{Ni} \mathrm{m}^{-2}, 10.51 \mathrm{~g} \mathrm{~Pb} \mathrm{~m}^{-2}$, and $23.88 \mathrm{~g} \mathrm{Zn} \mathrm{m}^{-2}$ (Table 2) since the 1900s. The atmospheric inventory for $\mathrm{Zn}$ was the highest, reaching $1.258 \mathrm{~g} \mathrm{~m}^{-2}$, while it was the lowest for $\mathrm{Cd}$, only $0.075 \mathrm{~g} \mathrm{~m}^{-2}$. Those findings were comparable to values reported in Europe from peat bogs, which were thought to receive pollutants solely from atmospheric deposition (Yang et al. 2002). Although total inventory of $\mathrm{Cd}$ was the lowest, percentage proportion of atmospheric $\mathrm{Cd}$ was the highest, probably attributed to widely fertilizer usage to the intensive agricultural land in the neighboring areas (Zhang and Shan 2008). Whereas the 
percentage proportion of atmospheric $\mathrm{Cr}$ was the lowest (3\%). Proportions of atmospheric deposition for $\mathrm{Ni}, \mathrm{Pb}$, $\mathrm{Cu}$, and $\mathrm{Zn}$ were $11.96,8.68,6.10$, and $4.42 \%$. Those findings clearly revealed that atmospheric inputs for $\mathrm{Cd}$ and $\mathrm{Ni}$ were relatively enhanced both by LRT metals and local anthropogenic activities.

\section{Conclusions}

As an example for many remote lakes in Tibetan Plateau, this study conducted in Lake Ngoring illustrates that concentrations and fluxes of atmospheric trace metals in the Lake Ngoring sediments generally show a very slow increase since the 1900 s followed by a rapid increase since the 1960s, in parallel to the rapid urbanization and economic development of the neighboring regions. Inventory estimations revealed that about one third of $\mathrm{Cd}$ was input by atmospheric deposition, and the proportion was about $10 \%$ for the other five studied trace metals.

Acknowledgments The authors gratefully acknowledge Wei Zhang, Nan Li and Pei Lei for analytical and technical help. This work was supported by the Planning Program of the Chinese Academy of Sciences (YSW2013B02).

\section{References}

Appleby PG (2002) Chronostratigraphic techniques in recent sediments. In: Last W, Smol J (eds) Tracking environmental change using lake sediments, developments in paleoenvironmental research, 1st edn. Springer, Netherlands, pp 171-203

Benoit G, Rozan TF (2001) ${ }^{210} \mathrm{~Pb}$ and ${ }^{137} \mathrm{Cs}$ dating methods in lakes: a retrospective study. J Paleolimnol 25(4):455-465

Bing HJ, Wu YH, Sun ZB, Yao SC (2011) Historical trends of heavy metal contamination and their sources in lacustrine sediment from Xijiu Lake, Taihu Lake Catchment, China. J Environ Sci China 23(10):1671-1678

Boutron CF, Gorlach U, Candelone JP, Bolshov MA, Delmas RJ (1991) Decrease in anthropogenic lead, cadmium and zinc in Greenland snows since the late 1960s. Nature 353(6340): 153-156

Carrera G, Fernández P, Vilanova RM, Grimalt JO (2001) Persistent organic pollutants in snow from European high mountain areas. Atmos Environ 35(2):245-254

Covelli S, Fontolan G (1997) Application of a normalization procedure in determining regional geochemical baselines. Environ Geol 30(1-2):34-45

Dai JC, Song JM, Li XG, Yuan HM, Li N, Zheng GX (2007) Environmental changes reflected by sedimentary geochemistry in recent 100 years of Jiaozhou Bay, North China. Environ Pollut 145(3):656-667

Franz TP, Eisenreich SJ (1998) Snow scavenging of polychlorinated biphenyls and polycyclic aromatic hydrocarbons in Minnesota. Environ Sci Technol 32(12):1771-1778

Han YM, Jin ZD, Cao JJ, Posmentier ES, An ZS (2007) Atmospheric $\mathrm{Cu}$ and $\mathrm{Pb}$ deposition and transport in lake sediments in a remote mountain area, northern China. Water Air Soil Pollut 179: $167-181$
Han YM, Cao JJ, Kenna TC, Yang BZ, Jin ZD, Wu F, An ZS (2011) Distribution and ecotoxicological significance of trace element contamination in a similar to $150 \mathrm{yr}$ record of sediments in Lake Chaohu, Eastern China. J Environ Monitor 13(3):743-752

Jeffries DS, Snyder WR (1981) Atmospheric deposition of heavy metals in central Ontario. Water Air Soil Pollut 15:127-152

Jin ZD, Han YM, Chen L (2010) Past atmospheric Pb deposition in Lake Qinghai, northeastern Tibetan Plateau. J Paleolimnol 43(3):551-563

Jin ZD, Li XD, Zhang B, Han YM, Zheng GL (2013) Geochemical records in Holocene lake sediments of northern China: implication for natural and anthropogenic inputs. Quatern Int 304:200-208

Lantzy RJ, Mackenzie FT (1979) Atmospheric trace metals: global cycles and assessment of man's impact. Geochim Cosmochim Acta 43(4):511-525

Madsen PP (1981) Peat bog records of atmospheric mercury deposition. Nature 293(5828):127-130

Nriagu JO (1989) A global assessment of natural sources of atmospheric trace-metals. Nature 338(6210):47-49

Nriagu JO (1996) A history of global metal pollution. Science 272(5259):223-224

Pacyna JM, Pacyna EG (2001) An assessment of global and regional emissions of trace metals to the atmosphere from anthropogenic sources worldwide. Environ Rev 9:269-298

Shotyk W, Weiss D, Appleby PG, Cheburkin AK, Frei R, Gloor M, Kramers JD, Reese S, Van der Knaap WO (1998) History of atmospheric lead deposition since 12, $37014 \mathrm{C}$ yr BP from a Peat Bog, Jura Mountains, Switzerland. Science 281(5383):1635-1640

Summers JK, Wade TL, Engle VD, Malaeb ZA (1996) Normalization of metal concentrations in estuarine sediments from the Gulf of Mexico. Estuaries 19(3):581-594

Vile MA, Wieder RK, Novak M (2000) 200 years of Pb deposition throughout the Czech Republic: patterns and sources. Environ Sci Technol 34(1):12-21

VonGunten HR, Sturm M, Moser RN (1997) 200-year record of metals in lake sediments and natural background concentrations. Environ Sci Technol 31(8):2193-2197

Wang XP, Yang HD, Gong P, Zhao X, Wu GJ, Turner S, Yao TD (2010) One century sedimentary records of polycyclic aromatic hydrocarbons, mercury and trace elements in the Qinghai Lake, Tibetan Plateau. Environ Pollut 158:3065-3070

Xue B, Yao SC, Xia WL, Zhu YX (2010) Some sedimentgeochemical evidence for the recent environmental changes of the lakes from the middle and lower Yangtze River basin, China. Quatern Int 226(1):29-37

Yang HD, Rose NL, Battarbee RW, Monteith D (2002) Trace metal distribution in the sediments of the whole lake basin for Lochnagar, Scotland: a palaeolimnological assessment. Hydrobiologia 479:51-61

Yang RQ, Yao TD, Xu BQ, Jiang GB, Xin XD (2007) Accumulation features of organochlorine pesticides and heavy metals in fish from high mountain lakes and Lhasa River in the Tibetan Plateau. Environ Int 33:151-156

Yang HD, Battarbee RW, Turner SD, Rose NL, Derwent RG, Wu GJ, Yang RQ (2010) Historical reconstruction of mercury pollution across the Tibetan Plateau using lake sediments. Environ Sci Technol 44:2918-2924

Zan FY, Huo SL, Xi BD, Zhu CW, Liao HQ, Zhang JT, Yeager KM (2012) A 100-year sedimentary record of natural and anthropogenic impacts on a shallow eutrophic lake, Lake Chaohu, China. J Environ Monitor 14:804-816

Zhang H, Shan BQ (2008) Historical records of heavy metal accumulation in sediments and the relationship with agricultural intensification in the Yangtze-Huaihe region, China. Sci Total Environ 399(1-3):113-120 